\title{
PENGARUH PERTUMBUHAN EKONOMI, PENDIDIKAN DAN PENGANGGURAN TERHADAP KEMISKINAN DI PROVINSI JAMBI
}

\author{
Yolanda Sari ${ }^{1}$ \\ Dosen Tetap Universitas Muhammadiyah Jambi ${ }^{1}$ \\ yolandasari2711@gmail.com \\ Antony Falianto ${ }^{2}$ \\ Mahasiswa Universitas Muhammadiyah $\mathrm{Jambi}^{2}$
}

\section{Ringkasan}

Permasalahan strategis di pemerintahan Provinsi Jambi tidak jauh berbeda dengan di pemerintahan pusat (problem nasional), yakni masih tingginya angka kemiskinan di Provinsi Jambi. Oleh karena itu, kemiskinan menjadi tanggung jawab bersama, terutama pemerintah sebagai penyangga proses perbaikan kehidupan masyarakat dalam sebuah pemerintahan, untuk segera mencari jalan keluar dengan merumuskan langkah-langkah yang sistematis dan strategis sebagai upaya pengentasan kemiskinan. Penelitian ini bertujuan untuk menganalisis pengaruh pertumbuhan ekonomi, pendidikan dan pengangguran terhadap kemiskinan di Provinsi Jambi baik secara parsial maupun secara simultan.

Data yang digunakan dalam penelitian ini adalah data sekunder berupa data pertumbuhan ekonomi, pendidikan, pengangguran dan kemiskinan di Provinsi Jambi pada tahun 2004-2019. Metode pengolahan data menggunakan analisis regresi linier berganda.Hasil analisis untuk persamaan regresi linier berganda adalah sebagai berikut: $\log Y=7,800-0,219 \log X 1-0,406 \log X 2+0,036 \log X 3+$ e dengan X1 Pendidikan, X2 Pertumbuhan Ekonomi, X3 Pengangguran dan Y adalah Kemiskinan di Provinsi Jambi. Kemudian dari hasil analisis diperoleh hasil bahwa X1, X2 dan X3 berpengaruh signifikan terhadap Y. Berdasarkan hasil penelitian ini dapat disimpulkan beberapa hal sebagai berikut: 1) variabel pertumbuhan ekonomi (X1) dan pendidikan (X2) berpengaruh negatif dan signifikan terhadap Kemiskinan (Y). Dan variabel pengagguran (X3) berpengaruh positif dan signifikan terhadap kemiskinan (Y) di Provinsi Jambi Tahun 2004-2019. 2) Secara simultan diperoleh bahwa Pertumbuhan Ekonomi (X1), Pendidikan (X2) Dan Pengangguran (X3) mempunyai pengaruh yang positif dan signifikan terhadap Kemiskinan (Y) di Provinsi Jambi periode 2004-2019.

Kata kunci : Pendidikan, Pertumbuhan Ekonomi, Pengangguran, Kemiskinan.

\section{PENDAHULUAN}

Permasalahan strategis di pemerintahan Provinsi Jambi tidak jauh berbeda dengan di pemerintahan pusat (problem nasional), yakni masih tingginya angka kemiskinan di Provinsi Jambi. Oleh karena itu, kemiskinan menjadi tanggung jawab bersama, terutama pemerintah sebagai penyangga proses perbaikan kehidupan masyarakat dalam sebuah pemerintahan, untuk segera mencari jalan keluar dengan merumuskan langkah-langkah yang sistematis dan strategis sebagai upaya pengentasan kemiskinan. Selain itu terkait dengan target tujuan pembangunan millenium yang harus tercapai pada tahun 2015, maka Provinsi Jambi masih harus bekerja 
keras untuk dapat mencapai target tersebut, mengingat upaya penanggulangan kemiskinan bukan merupakan hal yang mudah untuk dilaksanakan.

Secara umum jumlah penduduk miskin di Provinsi Jambi mengalami penurunan dari tahun 2004 sampai 2009, yaitu dari 325.100 ribu jiwa menjadi 245.000 ribu jiwa, setelah itu tahun 2010 jumlah penduduk miskin kembali naik menjadi 260.400 ribu jiwa. Di tahun 2010 sampai 2019 jumlah penduduk miskin Provinsi Jambi mengalami penurunan dan kenaikan disebabkan tidak stabilnya pertumbuhan ekonomi di Provinsi Jambi. Data di atas juga menunjukkan jumlah dari seluruh Provinsi Jambi setiap tahunnya. Rata-rata jumlah penduduk di Provinsi jambi 2.736.423,4 Juta Jiwa sedangkan Rata-rata jumlah penduduk miskin di Provinsi Jambi 268.947,33 Jiwa. Menurut indikator kemiskinan BPS, terlihat pada tahun 2004 jumlah penduduk miskin 325.100 Jiwa menjadi 274.320 Jiwa pada tahun 2019, ini berarti kebijakan-kebijakan dilaksanakan dengan baik meskipun tetap saja angka kemiskinan Provinsi Jambi masih tergolong tinggi dan tidak mendorong pembangunan lebih baik sama sekali. Tingginya persentase penduduk miskin di suatu wilayah akan berpengaruh pada rendahnya daya beli masyarakat di wilayah tersebut. Hal ini karena umumnya pendapatan penduduk miskin tersebut sangat rendah sehingga dari segi pendapatan perkapita juga rendah, apalagi rata-rata jumlah anggota rumah tangga penduduk miskin umumnya lebih banyak dari rumah tangga penduduk tidak miskin sehingga rata-rata pendapatan perkapita penduduk tersebut relatif lebih rendah. Keadaan ini akan lebih parah lagi jika tingkat pengangguran di wilayah tersebut juga tinggi.

Pertumbuhan ekonomi dan kemiskinan mempunyai keterkaitan yang erat. Terdapat pendapat bahwa pertumbuhan yang cepat berakibat buruk terhadap kaum miskin, karena mereka akan tergilas dan terpinggirkan oleh perubahan struktural pertumbuhan modern. Ada juga pendapat bahwa konsentrasi penuh untuk pengentasan kemiskinan akan memperlambat tingkat pertumbuhan ekonomi, karena dana pemerintah akan habis untuk penanggulangan kemiskinan sehingga proses pertumbuhan ekonomi akan melambat (Todaro, 2000).

Pertumbuhan ekonomi di Provinsi Jambi selama tahun 2004-2019 selalu mengalami peningkatan, dari tahun 2004 (Rp. 62.022.696) sampai dengan tahun 2019 (Rp. 149.264.615). Kuantitas dan kualitas sumber daya manusia akan berpengaruh terhadap pembangunan ekonomi suatu wilayah. Kuantitas sumber daya manusia dapat dilihat dari jumlah penduduknya. Kualitas Sumber Daya Manusia juga dapat dilihat dari tingkat pendidikannya. Menurut Todaro pendekatan modal manusia (human capital) berfokus pada kemampuan tidak 
langsung untuk meningkatkan utilitas dengan meningkatkan pendapatan (Todaro, 2000). Dengan melakukan investasi pendidikan maka akan meningkatkan produktivitas, peningkatan produktivitas akan meningkatkan pendapatan, pendapatan yang cukup akan mampu mengangkat kehidupan seseorang dari kemiskinan.

Dengan adanya tingkat pendidikan yang tinggi atau memadai akan memberikan kemampuan bagi lulusan SMA/Aliyah yang menjadikan sumber daya manusia berkualitas dan memeberikan efektivitas produksi yang akhirnya dapat menyumbang pertumbuhan ekonomi suatu wilayah. Masalah baru yang timbul ketika terjadi peningkatan jumlah lapangan kerja yang tidak sebanding dengan jumlah lulusan. Masalah ini memang selalu menjadi suatu persoalan yang perlu dipecahkan dalam perekonomian suatu wilayah. Tinggi nya angka pengangguran tidak hanya menimbulkan masalah masalah dibidang ekonomi, melainkan masalah dibidang soasial seperti kemiskinan dan kerawanan.

Jumlah pengangguran di Provinsi Jambi terus berfluktuasi setiap tahunnya, ini menunjukan bahwa penggangguran masih menjadi permasalahan di Provinsi Jambi, dengan jumlah pengangguran tertinggi terjadi pada tahun 2015 sebesar 133.964 jiwa, dan jumlah pengagguran terendah terjadi pada tahun 2012 sebesar 42.296 jiwa. Pengangguran muncul karena rendahnya tingkat pertumbuhan permintaan tenaga kerja disemua sektor. Tingkat penganguran yang tinggi dapat menyebabkan menurunnya tingkat kemakmuran dan kesejahteraan dalam masyarakat. Atas dasar permasalahan diatas maka penelitian ini bertujuan untuk menganalisis pengaruh pertumbuhan ekonomi, pendidikan dan pengangguran terhadap kemiskinan di Provinsi Jambi.

\section{TINJAUAN TEORITIS}

\section{Kemiskinan}

Badan Perencanaan Pembangunan Nasional (Bappenas) mendefinisikan kemiskinan sebagai kondisi dimana seseorang atau sekelompok orang tidak mampu memenuhi hak-hak dasarnya untuk mempertahankan dan mengembangkan kehidupan yang bermartabat. Hak-hak dasar antara lain: (1) Terpenuhinya kebutuhan pangan; (2) Kesehatan, pendidikan, pekerjaan, perumahan, air bersih, pertanahan, sumberdaya alam dan lingkungan; (3) Rasa aman dari perlakuan atau ancaman tindak kekerasan; (4) Hak untuk berpartisipasi dalam kehidupan sosial-politik (Bappenas, 2004).

\section{Faktor-faktor yang Mempengaruhi Kemiskinan}

1. Pendidikan 
Pendidikan merupakan salah satu bentuk modal manusia (human capital) yang menunjukkan kualitas Sumber Daya Manusia (SDM). Pendekatan modal manusia berfokus pada kemampuan tidak langsung untuk meningkatkan utilitas dengan meningkatkan pendapatan. Investasi dalam modal manusia akan terlihat lebih tinggi manfaatnya apabila kita bandingkan antara total biaya pendidikan yang dikeluarkan selama menjalani pendidikan terhadap pendapatan yang nantinya akan diperoleh ketika mereka sudah siap bekerja.

\section{Pertumbuhan Ekonomi}

Pertumbuhan ekonomi merupakan suatu proses kenaikkan output nasional suatu periode tertentu terhadap periode sebelumnya. Dalam perkembangannya terdapat banyak teori mengenai pertumbuhan ekonomi, antara lain: teori pertumbuhan klasik, dan teori pertumbuhan neoklasik (Todaro, 2000).

\section{Pengangguran}

Pengangguran atau tuna karya adalah istilah untuk orang yang tidak bekerja sama sekali, sedang mencari kerja, bekerja kurang dari dua hari selama seminggu, atau seseorang yang sedang berusaha mendapatkan pekerjaan yang layak. Menurut Sukirno (2004), pengangguran adalah seseorang yang sudah digolongkan dalam angkatan kerja yang secara aktif sedang mencari pekerjaan pada suatu tingkat upah tertentu, tetapi tidak dapat memperoleh pekerjaan yang diinginkannya. Pengangguran seringkali menjadi masalah dalam perekonomian karena dengan adanya pengangguran, produktivitas dan pendapatan masyarakat akan berkurang sehingga dapat menyebabkan timbulnya kemiskinandan masalah-masalah sosiallainnya. Pengangguran adalah masalah makro ekonomi yang mempengaruhi manusia secara tidak langsung dan paling berat. Bagi kebanyakan orang, kehilangan pekerjaan berarti menurunnya standar kehidupan dan tekanan psikologis (Mankiw, 2000).

\section{METODE PENELITIAN}

Data yang digunakan dalam penelitian ini adalah data sekunder berdasarkan rentang waktu (time series) periode 2004-2019 berupa data Pertumbuhan Ekonomi, Pendidikan, Pengangguran, serta Kemiskinan. Sumber data yang digunakan dalam penelitian ini berasal dari Badan Pusat Statistik (BPS) Provinsi Jambi.

Analisis data yang digunakan dalam penelitian ini adalah analisis yang bersifat deskriptif dan kuantitatif dengan alat analisis regresi linier berganda untuk menganalisis apakah Pertumbuhan Ekonomi, Pendidikan, dan Pengangguran berpengaruh terhadap Kemiskinan di Provisi Jambi tahun 2004-2019. 


$$
\begin{gathered}
Y=\beta_{0}+\beta_{1} X_{1}+\beta_{2} X_{2}+\beta_{3} X_{3}+e \\
\log Y=\beta_{0}+\beta_{1} \log X_{1}+\beta_{2} \log X 2+\beta_{3} \log X_{3}+e
\end{gathered}
$$

Keterangan:

$$
\begin{array}{ll}
\mathrm{Y} & =\text { Tingkat Kemiskinan } \\
\beta_{0} & =\text { Konstanta } \\
\beta_{1}, \beta_{2}, \beta_{3} & =\text { Koefisien Regresi } \\
\mathrm{X} 1 & =\text { Pendidikan } \\
\mathrm{X} 2 & =\text { Pertumbuhan Ekonomi } \\
\mathrm{X} 3 & =\text { Pengangguran } \\
\mathrm{e} & =\text { Error term }
\end{array}
$$

\begin{tabular}{|c|c|c|c|c|}
\hline \multirow{2}{*}{\multicolumn{2}{|c|}{ Model }} & $\begin{array}{c}\text { Unstandardized } \\
\text { Coefficients }\end{array}$ & \multirow[b]{2}{*}{$\mathrm{t}$} & \multirow[b]{2}{*}{ Sig. } \\
\hline & & $\mathrm{B}$ & & \\
\hline & (Constant) & 7,800 & 5,460 &, 000 \\
\hline & LOG_X1_PE &,- 219 & $-2,959$ &, 012 \\
\hline & $\mathrm{LOG}_{-}^{-} \mathrm{X} 2^{-} \mathrm{PD}$ &,- 406 & $-2,105$ & 057 \\
\hline & LOG_X3_PG & ,036 &, 430 & 675 \\
\hline
\end{tabular}

\section{HASIL PEMBAHASAN}

Analisis ini untuk mengetahui arah hubungan antara variabel Pertumbuhan Ekonomi, Pendidikan dan Pengangguran dengan variabel Kemiskinan apakah positif atau negatif dan untuk mengetahui sejauh mana variabel independent mempengaruhi variabel dependen dengan menggunakan program SPSS versi 26.0, dimana hasil hipotesis pengujian model linier berganda dapat dilihat sebagai berikut :

\section{Tabel 1. Hasil Analisis Regresi}

Sumber: Data diolah (2020)

Dari hasil regresi diatas maka regresi berganda yang digunakan dalam persamaan regresi sebagai berikut :

$$
\begin{gathered}
\log Y=\beta_{0}-\beta_{1} \log X_{1}-\beta_{2} \log X_{2}+\beta_{3} \log X_{3}+e \\
\log Y=7,800-0,219 \log X_{1}-0,406 \log X_{2}+0,036 \log X_{3}+e
\end{gathered}
$$

Nilai konstanta $\left(\beta_{0}\right)$ sebesar 7,800 menyatakan apabila variabel Pertumbuhan Ekonomi (X1), Pendidikan (X2) dan Pengagguran (X3) sama dengan nol atau konstan, maka 
Kemiskinan (Y) mengalami peningkatan sebesar 7,800 persen. Sedangkan koefisien regresi variabel Pertumbuhan Ekonomi (X1) di peroleh nilai sebesar (-)0,219 persen, artinya apabila terjadi kenaikan atau peningkatan Pertumbuhan ekonomi sebesar 1 persen, maka dapat menurunkan kemiskinan sebesar (-)0,219 persen. Atau sebaliknya jika Pertumbuhan Ekonomi terjadi penurunan sebesar 1 persen, maka dapat meningkatkan kemiskinan sebesar (-)0,219 persen. Lalu koefisien regresi variabel Pendidikan (X2) diperoleh nilai sebesar -0,406 persen, artinya apabila terjadi kenaikan atau peningkatan terhadap Pendidikan sebesar 1 persen maka akan menurunkan kemiskinan sebesar (-)0,406 persen. Begitu pula sebaliknya, jika Pendidikan terjadi penurunan sebesar 1 persen, maka akan dapat meningkatkan kemiskinan sebesar (),406 persen. Selanjutnya juga koefisien variabel Pengangguran (X3) di peroleh nilai sebesar 0,036 persen, artinya apabila terjadi kenaikan atau peningkatan terhadap pengagguran sebesar 1 persen, maka akan meningkatkan kemiskinan sebesar 0,036 persen, sebaliknya jika Pengangguran terjadi penurunan sebesar 1 persen, maka dapat menurunkan kemiskinan sebesar 0,036 persen.

Tabel 2. Hasil Uji Parsial (Uji-t)

\begin{tabular}{|c|c|c|c|c|c|c|}
\hline \multirow{2}{*}{\multicolumn{2}{|c|}{ Model }} & \multicolumn{2}{|c|}{$\begin{array}{l}\text { Unstandardized } \\
\text { Coefficients }\end{array}$} & \multirow{2}{*}{$\begin{array}{c}\text { Standardized } \\
\text { Coefficients } \\
\text { Beta }\end{array}$} & \multirow[b]{2}{*}{$\mathrm{t}$} & \multirow[b]{2}{*}{ Sig. } \\
\hline & & $\mathrm{B}$ & Std. Error & & & \\
\hline 1 & (Constant) & 7,800 & 1,429 & & 5,460 &, 000 \\
\hline & LOG_X1_PE &,- 219 &, 074 &,- 601 & $-2,959$ & ,012 \\
\hline & $\mathrm{LOG}^{-} \mathrm{X} 2{ }^{-} \mathrm{PD}$ &,- 406 & 193 &,- 504 & $-2,105$ & 057 \\
\hline & LOG X3 PG & ,036 & ,084 & , 102 & ,430 & ,675 \\
\hline
\end{tabular}

Sumber: Data diolah (2020)

$\mathrm{t}-$ Tabel $=(\mathrm{a} / 2 ; \mathrm{n}-\mathrm{k}-1)=(0,05 / 2 ; 16-3-1)=(0,025 ; 12)=2,178$

Berdasarkan Uji Parsial (Uji-t) diatas dapat dilihat hasil terhadap masing-masing variabel yaitu Pertumbuhan Ekonomi, Pendidikan, dan Pengagguran terhadap variabel kemiskinan dapat dianalisis sebagai berikut :

Hasil Perhitungan untuk variabel Pertumbuhan Ekonomi (X1) dapat disimpulkan bahwa nilai $t_{\text {hitung }}>t_{\text {tabel }}$ yaitu sebesar (-)2,959>2,178 dengan probabilitas sebesar 0,012 yang nilainya di bawah 0,05. Dengan hal ini menunjukan pengaruh negatif dan signifikan antara Pertumbuhan Ekonomi (X1) terhadap Kemiskinan (Y). Demikian H0 ditolak H1 diterima, sehingga hipotesis yang menyatakan pengaruh negatif dan signifikan antara Pertumbuhan Ekonomi (X1) secara parsial terhadap Kemiskinan (Y) diterima. Artinya, ketika tingkat pertumbuhan ekonomi di suatu daerah mengalami peningkatan maka tingkat kemiskinan di daerah tersebut akan 
mengalami penurunan. Hasil penelitian ini sesuai dengan penelitian oleh Ni Wayan Ria Suadnyani dan Ida Bagus Darsana yang menyatakan bahwa PDRB sebagai indikator pertumbuhan ekonomi berpengaruh negatif terhadap kemiskinan. Hal ini telah sesuai dengan teori dan kerangka berpikir yang dikembangkan. Pertumbuhan Ekonomi merupakan pertambahan output atau pendapatan perkapita suatu wilayah. Dengan naiknya Pertumbuhan Ekonomi dapat disimpulkan bahwa pertambahan pendapatan masyarakat dari tahun sebelumnya juga meningkat.

Berikutnya hasil perhitungan untuk variabel Pendidikan (X2) dapat disimpulkan bahwa nilai $t_{\text {hitung }}>t_{\text {tabel }}$ yaitu sebesar (-)2,105<2,178 dengan probabilitas sebesar 0,057 yang nilainya di atas 0,05 . Dengan hal ini menunjukan tidak berpengaruh negatif dan tidak signifikan antara Pendidikan (X2) terhadap Kemiskinan (Y). Demikian H0 diterima H1 ditolak, sehingga hipotesis yang menyatakan ada pengaruh negatif dan signifikan antara Pendidikan (X2) secara parsial terhadap Kemiskinan (Y) ditolak. Hal ini dikarenakan mayoritas mata pencaharian masyarakat Provinsi Jambi adalah bertani, berjualan dan melaut (istilah dalam bahasa Jambi mencari ikan di sungai batanghari). Untuk menjadi petani masyarakat tidak harus bisa memiliki pendidikan yang tinggi. Sehingga masyarakat beranggapan bahwa meskipun mereka tidak dapat berpendidikan tinggi akan tetapi mereka masih bisa bekerja.

Sedangkan hasil perhitungan untuk variabel Pengagguran (X3) dapat disimpulkan bahwa nilai $t_{\text {hitung }}<t_{\text {tabel }}$ yaitu sebesar $0,430<2,178$ dengan probabilitas sebesar 0,657 yang nilainya di atas 0,05 . Dengan hal ini menunjukan tidak ada pengaruh negatif dan tidak signifikan antara Pengagguran (X3) terhadap Kemiskinan (Y). Demikian H0 diterima H1 ditolak, sehingga hoptesis yang menyatakan ada pengaruh negatif dan signifikan antara Pengagguran (X2) secara parsial terhadap Kemiskinan (Y) ditolak. Artinya Provinsi Jambi masih tergolong agraris dan jumlah pengagguran sangat dipengaruhi oleh sektor pertanian, sektor pertanian itu sendiri sangat dipengaruhi oleh kondisi alam, cuaca, bahkan sangat mungkin dipengaruhi apabila terjadinya bencana. Pengagguran akan bertambah signifikan ketika terjadinya kemarau panjang sehingga para petani terpaksa menganggur karena tidak bisa bercocok tanam. Demikian hal nya manakala terjadi bencana banjir, maka sangat mengganggu pertanian. 
Tabel 3. Hasil Uji Simultan (Uji-F)

\begin{tabular}{|c|c|c|c|c|c|c|}
\hline & & $\begin{array}{l}\text { Sum of } \\
\text { Squares }\end{array}$ & Df & $\begin{array}{c}\text { Mean } \\
\text { Square }\end{array}$ & $\mathrm{F}$ & Sig. \\
\hline \multirow[t]{3}{*}{1} & Regression &, 010 & 3 & \multirow{3}{*}{$\begin{array}{l}, 003 \\
, 001\end{array}$} & \multirow[t]{3}{*}{5.509} & \multirow[t]{3}{*}{, $013^{b}$} \\
\hline & Residual & ,007 & 12 & & & \\
\hline & Total &, 018 & 15 & & & \\
\hline
\end{tabular}

a. Dependent Variable : LOG_Y_KM

b. Predictors: (Constant), LOG_X3_PG, LOG_X1_PE, LOG_X2_PD Sumber: Data diolah (2020)

F-tabel $=(\mathrm{k} ; \mathrm{n}-\mathrm{k})=(3 ; 16-3)=(3 ; 13)=3,41$

Berdasarkan tabel 5.3 di atas, di peroleh bahwa Fhitung $>$ Ftabel yaitu 5,509>3,81 dengan nilai signifikansi sebesar 0,013 yang nilainya dibawah 0,05 hal ini menunjukan bahwa semua variabel independent yaitu pertumbuhan ekonomi, pendidikan, dan pengagguran berpengaruh positif dan signifikan secara simultan (bersama-sama) terhadap kemiskinan di Provinsi Jambi periode 2004-2019. Penelitian ini membuktikan bahwa minimal satu dari variabel bebas berpengaruh signifikan terhadap variabel terikat yaitu terdapat pengaruh signifikan antara pertumbuhan ekonomi, oendidikan dan pengangguran terhadap kemiskinan di Provinsi Jambi. Hal ini menggambarkan bahwa antara pertumbuhan ekonomi, pendidikan dan pengangguran merupakan salah satu penyebab dari kenaikan dan penurunan kemiskinan di Provinsi Jambi.

Tabel 4. Hasil Uji Koefisien determinasi

\begin{tabular}{|l|r|r|r|r|}
\hline Model & $\mathrm{R}$ & \multicolumn{1}{|c|}{ R Square } & Adjusted R Square & $\begin{array}{c}\text { Std. Error of the } \\
\text { Estimate }\end{array}$ \\
\hline 1 &, $761^{\mathrm{a}}$ &, 579 &, 474 &, 02488 \\
\hline
\end{tabular}

a. Predictors: (Constant), LOG_X3_PG, LOG_X1_PE, LOG_X2_PD

Sumber: Data diolah (2020)

Dari tabel koefisien determinasi di atas, dapat dilihat bahwa angka koefisien determinasi (R Square) sebesar 0,579. Hal ini berarti hubungan antar variabel independent dengan variabel dependent sebesar 57,9\%. Dari angka tersebut dapat di ambil kesimpulan bahwa hubungan antara variabel independent dan dependent kuat. 
Besarnya Adjusted R Square $\left(\mathrm{R}^{2}\right)$ adalah 0,474. Hasil perhitungan statistik ini berarti kemampuan variabel independent dalam menerangkan variabel dependent sebesar 47,4\%, sedangkan sisanya sebesar 52,6\% diterangkan oleh faktor-faktor lain diluar model regresi yang dianalisis.

\section{Tabel 5. Hasil Uji Koefisien Korelasi Berganda}

\begin{tabular}{|l|r|r|r|r|}
\hline Model & R & R Square & Adjusted R Square & $\begin{array}{c}\text { Std. Error of the } \\
\text { Estimate }\end{array}$ \\
\hline 1 &, $761^{\mathrm{a}}$ &, 579 &, 474 &, 02488 \\
\hline
\end{tabular}

Predictors: (Constant), LOG_X3_PG, LOG_X1_PE, LOG_X2_PD

Sumber: Data diolah (2020).

Dari tabel diatas diketahui bahwa nilai signifikan $<0,000$, maka dikatakan korelasi antara variabel, dengan nilai $r=0,761$. Artinya terdapat hubungan yang kuat antara variabel Pertumbuhan Ekonomi (X1), Pendidikan (X2), Pengangguran (X3) terhadap Kemiskinan (Y) Provinsi Jambi periode 2004-2019.

\section{KESIMPULAN DAN SARAN}

\section{Kesimpulan}

Berdasarkan pembahasan dan hasil analisis data dalam penelitian ini, dapat diambil kesimpulan sebagai berikut:

1. Berdasarkan hasil koefisien regresi linear berganda, variabel pertumbuhan ekonomi (X1) dan pendidikan (X2) berpengaruh negatif dan signifikan terhadap Kemiskinan (Y). Dan variabel pengagguran (X3) berpengaruh positif dan signifikan terhadap kemiskinan (Y). Penelitian hipotesis secara parsial (Uji-t) menunjukan bahwa Pertumbuhan Ekonomi (X1) mempunyai pengaruh negatif dan signifikan terhadap Kemiskinan (Y) di Provinsi Jambi periode 2004-2019. Kemudian untuk variabel Pendidikan (X2) secara parsial Pendidikan (X2) tidak mempunyai pengaruh dan tidak signifikan terhadap Kemiskinan (Y) di Provinsi Jambi periode 2004-2019. Sedangkan untuk variabel Pengangguran (X3) secara parsial Pengangguran (X3) tidak mempunyai pengaruh dan signifikan terhadap Kemiskinan (Y) di Provinsi Jambi periode 2004-2019.

2. Berdasarkan dari hasil penelitian hipotesis secara simultan atau bersama-sama (Uji-F) ini diperoleh bahwa Pertumbuhan Ekonomi (X1), Pendidikan (X2) Dan Pengangguran (X3) secara bersama-sama (simultan) mempunyai pengaruh yang positif dan signifikan terhadap Kemiskinan (Y) di Provinsi Jambi periode 2004-2019. 


\section{Saran}

1. Pemerintah Provinsi Jambi diharapkan terus menjaga konsistensi dan bergerak cepat dalam meningkatkan pertumbuhan ekonomi, meningkatkan SDM yang baik lagi karena SDM yang kompeten sangat menunjanng meningkatnya perekonomian, juga mengelola SDA dengan sebaik-baiknya karena SDA juga menjadi salah satu aspek dalam pertumbuhan ekonomi, dimana SDA berperan sebagai bahan dasar setiap produksi.

2. Pemerintah Provinsi Jambi diharapkan serius menangani masalah pendidikan dengan memberikan beasiswa pendidikan sepenuhnya bagi masyarakat miskin di Provinsi Jambi selain itu pemerintah juga harus meningkatkan mutu dan kualitas pembelajaran yang lebih terfokus lagi pada membangun skill dan kualitas sumber daya manusia agar semua masyarakat yang tergolong miskin dapat menyelesaikan pendidikannya dan memiliki skill pengetahuan yang siap di dunia kerja.

3. Serta Pemerintah Provinsi Jambi diharapkan dapat lebih banyak lagi menyediakan lapangan pekerjaan yang padat karya, guna menekan angka pengangguran lebih rendah lagi, dan tetap dengan mengatur dan memastikan hasil atau pendapatan yang layak dan dapat mensejahterkan rakyat serta memberikan lebih banyak lagi membuat pelatihanpelatihan kepada penduduk Provinsi Jambi guna menjadikan kualitas sumber daya manusia yang lebih bermutu.

\section{DAFTAR PUSTAKA}

Arsyad, L. (2010) Ekonomi Pembangunan, Edisi Pertama. Yogyakarta: BPFE.

Bappenas. (2009) Laporan Pembangunan Manusia Indonesia 2009, Menuju Konsensus Baru Demokrasi dan Pembangunan Manusia Di Indonesia. Jakarta: BPS, UNDP.

Kuncoro, M. (2003). Metode Untuk Bisnisdan Ekonomi. Jakarta: Erlangga

Kuncoro, M. (2006). Ekonomi Pembangunan. Jakarta: Salemba Empat.

Mankiw, N.G. (2000). Teori Makro Ekonomi. Edisi Keempat. Terjemahan: Imam Nurmawan. Jakarta: Erlangga .

Mankiw, N.G. (2012). Pengantar Ekonomi Makro. Jakarta: Erlangga.

Suadnyani, N.W.R., \& Darsana, I.B. (2018) Pengaruh Pertumbuhan Ekonomi, Pengangguran, dan Pendapatan Terhadap Kemiskinan di Kabupaten Bangli. E-Jurnal EP Unud. Vol.7, No 5. Bali: Universitas Udayana.

Suharto, E. (2005) Membangun Masyarakat Memberdayakan Rakyat. Bandung: Alfa Beta. 
Suharto, E. (2009) Kemiskinan Dan Perlindungan Sosial Di Indonesia. Bandung: Alfa Beta.

Suparmoko. (2004) Pengantar Ekonomika Makro. Yogyakarta: BPFE.

Sukirno, S. (2004) Pengantar Teori Makro Ekonomi. Jakarta: PT. Raja Grafindo Persada.

Supriatna, T. (2002) Strategi Pembangunan Dan Kemiskinan. Jakarta: Rineke Cipta.

Soleh, A. (2017). Masalah ketenagakerjaan dan pengangguran di Indonesia. Jurnal Ilmiah Cano Ekonomos, 6(2), 83-92.

Soleh, A. (2018). Analisis dan Strategi Pengentasan Kemiskinan Di Provinsi Jambi. EKSIS: Jurnal Ilmiah Ekonomi dan Bisnis, 9(1), 79-90.

Soleh, A., Daniel, P. A., \& Siswoyo, S. (2019). Analisis Pengangguran Dan Kemiskinan Di Provinsi Jambi. Jurnal Development, 7(2), 98-107.

Todaro, M.P. (2000) Pembangunan Ekonomi Di Dunia Ketiga. Jakarta: Erlangga.

Todaro, M.P., \& Smith, S.C. (2003) Pembangunan Ekonomi Di Dunia Ketiga. Edisi Kedelapan. Jilid 2. Jakarta: Erlangga.

Wirawan, I.M.T.W., \& Sudarsana, A. (2015) Analisis Pengaruh Pendidikan, PDRB Perkapita, dan Tingkat Pengangguran Terhadap Jumlah Penduduk Miskin Provinsi Bali. E-Jurnal EP Unud. Vol.4, No.5. Bali: Universitas Udayana.

World Bank. (2004) Mewujudkan Pelayanan Umum Bagi Masyarakat Miskin. Jakarta: The World Bank. 